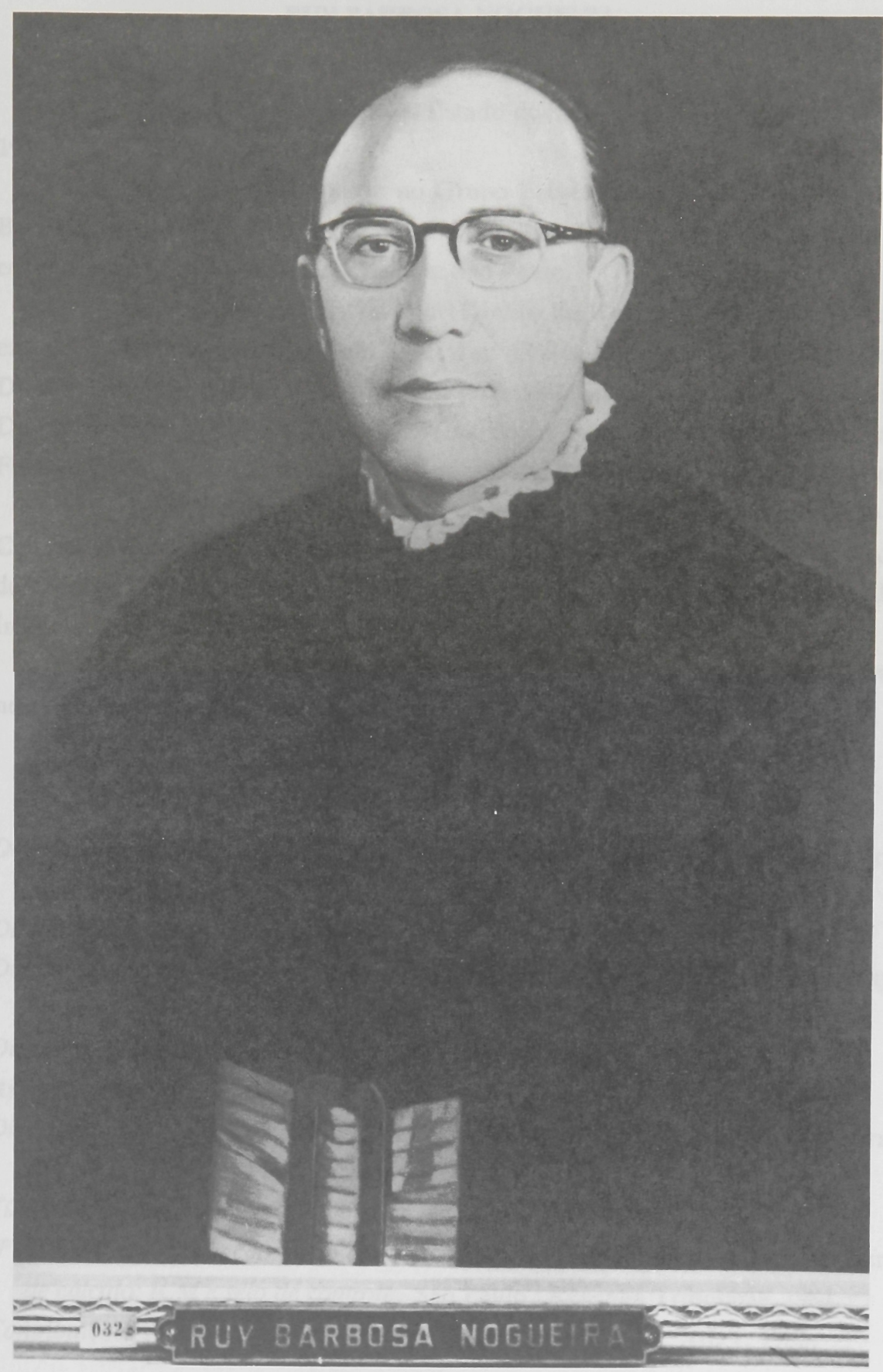





\section{RUY BARBOSA NOGUEIRA \\ (1974-1978)}

Nasceu em Jardinópolis, Estado de São Paulo, a 19 de setembro de 1919.

Fez o curso primário no Grupo Escolar Dr. Washington Luís, em Batatais, e o secundário, parte no Ginásio São José, dessa cidade, vindo a concluí-lo no Ginásio Oswaldo Cruz, em São Paulo.

Ingressou na Faculdade de Direito da Universidade de São Paulo em 1941, onde bacharelou-se em 1945. Em 1963 alcançou a livre-docência de Direito Tributário nesta Faculdade e em 1965 conquistou a cátedra, também em Direito Tributário. Esteve, desde 1954, na regência da cátedra de Ciência das Finanças, agora Direito Financeiro, em substituição ao professor Carvalho Pinto.

Foi diretor desta Faculdade de 1974 a 1978, além de ter presidido a Comissão de Legislação e Recursos da Universidade de São Paulo. Foi professor de Direito Tributário Comparado no curso de pós-graduação e presidente do Instituto Brasileiro de Direito Tributário.

Advogado militante por mais de 40 anos, é autor de diversas obras no extenso campo dos impostos, taxas e contribuições.

\section{Obras Publicadas}

Da interpretação e da aplicação das leis tributárias. São Paulo : Revista dos Tribunais, 1963.

Direito financeiro: curso de direito tributário. São Paulo : José Bushatsky, 1964.

Direito tributário: estudos de casos e problemas. São Paulo : José Bushatsky, 1969.

Direito tributário comparado. São Paulo : Saraiva, 1971.

Aspectos fundamentais do IPI e os vasilhames. São Paulo : Unidas, 1974.

Direito tributário aplicado, em colaboração com Paulo Roberto Cabral Nogueira.

Rio de Janeiro-São Paulo : Forense-EDUSP, 1975.

Túllio Ascarelli e o direito tributário do Brasil. São Paulo : IBDT, 1979.

IPI e ICM: a delucidação tecnológica; ICM e ISS: mercadorias e serviços; a base de cálculo; ICM e selo de controle. São Paulo : Resenha Tributária, 1981. Contribuições sociais e empresas urbanas e rurais. São Paulo : IBDT, 1985. 
Curso de direito tributário, de acordo com a Constituição Federal de 1988. São Paulo : Saraiva, 1989.

IPI, ICMS, ISS, contribuição de melhoria. São Paulo : Resenha Tributária, 1991. 